\title{
Implication of the Implementation of Free Irrigation Service Fee to the Federation of Irrigators Associations of NIA-UPRIIS Division I
}

\author{
Elizabeth V. Fullon, Anthony B. San Pedro, Jerickson D. J. Ruz, Rose Ann A. Sagun, \\ Anilyn A. Mariano, Ma. Theresa Florencondia
}

Department of Public Administration, Nueva Ecija University of Science and Technology, Cabanatuan City, the Philippines

Email: fullonelizabeth@gmail.com, anthonybasasanpedro@yahoo.com,jericksonruz@gmail.com,

roseannsagun16@gmail.com,marianoanilyn@gmail.com,matheresaflorencondia@yahoo.com

How to cite this paper: Fullon, E.V., Pedro, A.B.S., Ruz, J.D.J., Sagun, R.A.A., Mariano, A.A. and Florencondia, Ma.T. (2018) Implication of the Implementation of Free Irrigation Service Fee to the Federation of Irrigators Associations of NIA-UPRIIS Division I. Open Access Library Journal, 5: e4340. https://doi.org/10.4236/oalib.1104340

Received: January 15, 2018

Accepted: February 20, 2018

Published: February 23, 2018

Copyright ( $\odot 2018$ by authors and Open Access Library Inc.

This work is licensed under the Creative Commons Attribution International License (CC BY 4.0).

http://creativecommons.org/licenses/by/4.0/

\begin{abstract}
The administration of President Rodrigo R. Duterte has fulfilled one of their campaign promises, which is to reduce production cost and increase farmers' income. Thus, an amount of Two Billion Pesos (P 2,000,000,000.00) was provided in the budget of NIA under General Appropriations Act (GAA) of 2017 or RA 10,924 for the implementation of the free Irrigation Service Fee (ISF) program that commenced on the first cropping season of the year 2017. Through a qualitative research design, this study was able to describe the implication of the implementation of free ISF program to the Federation of Irrigators Association of NIA-UPRIIS, Division I. The implementation of the program brought sudden changes in the performance of the FIAs when it came to their operation and maintenance responsibilities. They became more aware of their responsibilities in the irrigation system. Assistance and support are still being given to them by NIA. However, when it comes to funds, they have to find ways to cover for their own expenses in canal clearing activities and other expenses related to their operation and maintenance responsibilities. Therefore, they agreed to collect seasonal dues from their members. The most visible implications of the implementation of the free ISF program were the reduction of production cost of the farmers and the associations were able to have better understanding of the importance of their role in sustaining and developing the irrigation system. By working hand in hand, the FIAs and NIA can manage to sustain the operations and maintenance of the irrigation system.
\end{abstract}

\section{Subject Areas}

General Management 


\section{Keywords}

Irrigators, Irrigation Service Fee, Sustainable Development

\section{Introduction}

The National Irrigation Administration (NIA) was established on June 1964 under the Republic Act (RA) 3601, as a Government Owned and Controlled Corporation (GOCC), and was mandated to develop and sustain the operation and maintenance of the irrigation systems all throughout the Philippines.

Later on, Presidential Decree (PD) No. 552 of 1974 amended RA 3601 and mandated NIA to collect Irrigation Service Fee (ISF) from its farmer beneficiaries to cover its operation and maintenance costs and to recover costs of construction within a reasonable period of time to the extent consistent with government policy. Aside from this, partial or full management of national irrigation systems was delegated to duly organized cooperatives or associations. Thus, the Irrigation Management Transfer (IMT) Program-an agreement between Irrigators Associations (IAs) and NIA was implemented. In this program, IAs are now responsible for the operations and maintenance of the laterals, sub-laterals, turnouts and farm ditches within their area of jurisdiction.

During the term of former President Joseph Estrada, the ISF was abolished, but was later revised to adoption of socialized irrigation fee system through Administrative Order No. 17 of August 1998. This effort was not successful. NIA was unable to cover for cost of operation and maintenance of existing systems and personnel salaries because of heavy losses. Given the situation, unpaid ISFs were accounted to farmer-beneficiaries and the payment of ISF was reinstated in 2002.

On the analysis of Frezoil Luz Decena, on the effects of various irrigation service fees for National Irrigation Systems in the Philippines, during the times when collection of ISF was existent, NIA was not successful in recovering its operations and maintenance costs. He concluded that the payment of ISF shall be strictly implemented and collection of unpaid ISF or back accounts shall not be taken for granted. Xuea C. \& Xinfeng W. suggested in their paper that the government should provide farmers with reasonable subsidies while formulating mandatory provisions constraints their behaviors.

Thus, in view of reducing production cost and increasing farmers' income, the current administration has fulfilled one of President Rodrigo Duterte's campaign promises-the implementation of free ISF program. This program has taken effect on the first cropping season of the year 2017. An amount of Two Billion Pesos (P 2,000,000,000.00) was provided in the budget of NIA under General Appropriations Act (GAA) of 2017 or RA 10,924.

With high hopes that history will not repeat itself, this study will explore the impact of the implementation of free ISF program to the FIAs of NIA-Upper 
Pampanga River Integrated Irrigation Systems (UPRIIS), Division I.

NIA-UPRIIS, Division I is located at Science City of Muñoz, Nueva Ecija. It has a total service area of 20723.81 hectares that cover some parts of Lupao, San Jose City, Science City of Muñoz, Llanera, Talavera, Sto. Domingo, Quezon and Licab, and has 15,701 farmer-beneficiaries.

To provide efficient and effective service, the service area of Division I was divided into three (3) Zonal areas. Zone I covers some areas in San Jose City and Lupao, Zone II covers areas in San Jose City, Talavera, Llanera and Science City of Muñoz, while Zone III covers areas in Sto. Domingo, Quezon and Licab, Nueva Ecija. Each zone is being represented by five (5) Federation of Irrigators Associations (FIAs). The SJC FIA in Zone I, SMHD FIA and MUNTALDOM FIA in Zone II, and the Lat. B Main FIA and QUELICADOM FIA in Zone III.

This study was intended to describe the implication of the implementation of free ISF program of NIA-UPRIIS Division I. The study aimed to:

1) Describe the operation of NIA-UPRIIS Division I upon the implementation of free ISF program;

2) Describe the performance of FIAs in their operation and maintenance responsibilities in compliance with the free ISF program; and

3) Determine the payment preference of FIAs.

\section{Significance of the Study}

The study is significant to the following:

- The program implementers and NIA employees. Since this program was re-implemented, careful analysis must be done to avoid the mistakes on its past implementation. Through this study, they will be able to identify possible loopholes that may affect the success of the program.

- The Federation of Irrigators Associations (FIAs). The result of this study will contribute to their realizations on their part or responsibilities in maintaining irrigation structures and facilities.

- To future researchers. This study may serve as reference in future studies regarding the effectiveness of free ISF program in the Philippines.

\section{Methodology}

This study used qualitative research design, which is a form of inquiry that analyzes information conveyed through language and behavior in natural settings.

It was used to capture expressive information not conveyed in quantitative data about beliefs, values, feelings, and motivations that underlie behaviors [1].

Purposive sampling was used in this research. It is a technique that aims to achieve a homogeneous sample whose units share similar characteristics or traits such as gender, background, occupation, etc. [2].

The researcher opted this sampling technique to address research questions that are specific to the characteristics of the group of interest, which is subsequently examined in detail. 
For this study, the researcher selected the five (5) FIA presidents of NIAUPRIIS Division I as respondents. They were chosen as representatives of the farmers under their area of jurisdiction. As presidents of the Federations, they are well aware of the actual situation, the needs and the preferences of the Irrigators Associations of NIA-UPRIIS Division I. The researcher provided semistructured questionnaire that serves as interview guide for data gathering (See Appendix A).

Couple of focus group discussions was also conducted by the researcher. It is a data collection method in a semi-structured group interview process for a specific topic [3]. Through this method, the researcher was able to have access to comparisons that was made by the participants based on their experiences. During the discussions issues such as the payment preference the farmers and the compliance of the FIAs to their responsibilities to the irrigation community were tackled.

\section{Results and Discussion}

\subsection{Operation of NIA-UPRISS Division I upon the Implementation of Free ISF}

Upon the implementation of the program, NIA was given an amount of Two Billion Pesos to cover its operations and maintenance costs. Thus, starting the first cropping season of 2017, ISF was no longer collected from the farmers.

Alongside with the implementation of the program is the renewal of modified IMT contract. When there was still ISF collection, part of the IMT contract agreement between NIA and the associations was the IA Share.

Since the responsibility of the operations and maintenance of laterals, sub-laterals, turnouts, and farm ditches belongs to the associations, they were given IA Share. It is a form of incentive that was given to associations whose collection efficiency reached 55\% and above. The incentive served as association's source of fund that they need in performing their responsibilities in the irrigation system. Now that the free ISF program was implemented, IA Share was no longer given to them.

“Ang nakikita ko na naging epekto ng pagkawala ng ISF ay iyong pagkawala ng IA Share. Kung dati ay may natatanggap kaming insentibo kapag nakakapasa kami sa koleksyon, ngayon wala na kasi nga wala naman ng koleksyon. Nawalan kami ng pagkukuhanan ng pondo sa pagpapalinis ng kanal."

Aside from the incentive, NIA was also providing help for the associations for their canal clearing activity. Before the implementation of the program, financial aid was given to associations based on the length of their canal. For earth or unlined canal, the remuneration was P750.00 per kilometer and P500.00 for lined canal.

Now that the program was implemented, the remuneration for canal clearing was reduced: $\mathbf{P} 500.00$ per kilometer for earth or unlined canal and 尹250.00 for lined canal. Clearly, this computation is not enough for the said canal clearing 
activity.

"Nung nawala po yung ISF, yung binibigay sa amin na tulong ng NIA para sa clearing ng kanal eh lumiit. Dati nasa 750 per kilometro yun ngayon 500 na lang. Kung sa experience kasi naming pagbabasehan, kapag nagpapalinis kami ng kanal ilang tao inuupahan naming, lima hanggang anim. Yung kanal kasi naming nasa 3 kilometers yun. Hindi naman po kaya yun ng isang araw lang. Pinakamatagal na palinis naming apat na araw. Ang upa naming sa mga naglilinis pumapalo ng 250 - 300, sabihin na natin na 300, magkano po yun, umaabot ng 7000 pesos kumpara sa matatanggap naming na tulong na 1500 pesos. Maliit po talaga. Pero naiintindihan namn po namin na responsibilidad naman kasi naming ang magpalinis."

Since the government has seen the shared responsibilities of the associations and NIA in maintaining and sustaining the irrigation systems, a subsidy will also be given to the associations for the year 2018 .

Based on the total irrigated and planted area of the association, a subsidy of P150.00 per hectares will be given to them.

However, they must pass the evaluation that will be conducted by NIA for them to obtain the said subsidy. Since the subsidy will be provided by the government, strict evaluation will be conducted. Some of the criteria for evaluation includes regular canal clearing activity, having regular monthly meetings, maintenance of existing structures within their area and assistance in water delivery and distribution.

With regards to NIAs response to farmers' request in terms of operations and maintenance works, the program implementation did not affect their performance. They are still heeding to the association's requests. Although, there are still delays in granting their requests due to lack of equipment to be used.

“Maayos pa rin ang serbisyo ng NIA sa amin. Kaso nga lang delay minsan yung request naming gaya ng pag backhoe ganun kasi madalas sira. Sana ngayong subsidize na, magkaroon na sila ng karagdagan at mga bagong equipment."

\subsection{Actions Taken by FIAs in Performing Their Responsibilities in the Operation and Maintenance of the Irrigation System, in Compliance with the Free ISF Program}

When the program was implemented, the responsibilities of the associations in the irrigation system were more emphasized.

Since not all the farmer-members of the different associations in Division I were aware of their responsibilities in the irrigation system, FIA leaders made efforts to make the farmers aware.

They called for General Assembly meeting and there, they discussed the shared responsibilities of the associations and NIA. Without any source of funds, they find it hard to perform their responsibilities, especially in canal clearing. They discussed with the members the importance of collecting funds. Thus, they made resolutions regarding the collection of seasonal dues to all their farmer- 
members. Collection of seasonal or annual dues was included in their bylaws.

They started collecting seasonal dues to all their members which amounts to P150.00. Since they are now collecting funds, they will be audited by NIA.

The associations provided financial plans wherein $60 \%$ of their fund was allocated for the maintenance and other operating expenses, and the remaining $40 \%$ is allocated for personal services.

With the funds that they collected, some of the associations were able to buy equipment such as grass cutters which they use for their canal clearing activity.

\subsection{Preference of FIAs with Regards to Payment or Non-Payment of ISF}

The word "free" gives us such an emotional charge that we perceive what is being offered as immensely more valuable as it really is [4].

Initially, there were doubts on the effectiveness of the program. Their initial thought was that history might repeat itself when ISF became free then was later on revoked during the administration of former president Estrada.

"Nung una halo yung naramdaman naming. Natuwa kami pero nandun yung pangamba kasi baka magaya nung panahon ni Erap na nalibre tapos binawi. Naging utang tuloy namin yun."

There were fears that the responsibilities on irrigation system will be neglected and associations will be abolished.

Subsidies can bring certain disadvantage to farmers. They may encourage inefficiency by relying more in the subsidy money that offered by the government [5].

But then, their understanding on the program became deeper. They realize the importance of the role of their associations and the importance of their active participation in performing their responsibilities in the irrigation system.

Associations now see that the program seems to be more helpful in the improvement of farmers' quality of life and in the sustainability of the irrigation system.

They are now fully supporting the program with the vision of making their associations more empowered.

"Dahil po naipatupad ang programa, napatunayan natin na may isang salita ang presidente. At kami, bilang balik sa kabaitan ng gobyerno, gagawin po namin ang lahat para makatugon sa aming responsibilidad."

\section{Conclusion and Recommendation}

\subsection{Conclusion}

The changes that were brought by the implementation of free ISF program affect the FIAs in performing their responsibilities in the operation and maintenance of irrigation system. However, the implementation of the program did not affect the performance of NIA in terms of addressing the farmers' request. NIA still manages to assist the farmers with their needs [6]. 
Without any source of fund, associations find it hard to perform their obligations such as canal clearing activities. They cannot just rely on the canal remuneration that is being given to them as aid in canal clearing because it is too small.

Since a subsidy will also be given to the associations, their efforts in performing their responsibilities became more visible. They will now be accountable for they have to pass the evaluation that will be conducted before the subsidy which will be given to them [7].

The farmers, not only the associations, have seen the impact of free ISF in their lives. Their production cost was reduced and they were able to have better understanding in the importance of their role in sustaining and developing the irrigation system.

\subsection{Recommendations}

Now that NIA has been subsidized, they must take actions in providing more efficient service to the farmers. They can request for fund for additional equipment so that they can address farmers' concern more without any delays.

Aside from collecting funds, associations can also encourage the farmermembers to instill bayanihan since they are now more aware of their responsibilities in the irrigation system.

Funds that will be collected by the associations must be clearly accounted to avoid possible issues, such as corruption that may threaten the association.

At all cost, NIA and the associations must support each other to be able to develop and sustain the irrigation system.

Now that NIA has been subsidized, they must take actions in providing more efficient service to the farmers.

\section{References}

[1] Badiani, B. and Jessoe, K. (2012) Impact of Electricity Subsidies on Groundwater Extraction and Agricultural Production. University of California, California.

[2] Decena, F. (2016) Analysis of the Effects of Various Irrigation Service Fees for National Irrigation Systems in the Philippines. Los Baños, Laguna, Philippines. http://ap.fftc.agnet.org/ap_db.php?id=585\&print=1

[3] Husain, I. (2004) Have Low Irrigation Service Charges Disadvanataged the Poor. International Water Management Institute, Sri Lanka.

[4] Ruta, D. (2012) A Commitment Theory of Subsidy Agreements. University of Western Ontario, World Trade Organization.

[5] Small, L., Adriano, M. and Edward, D. (1986) Regional Study on Irrigation Service Fee. International Irrigation Management Institute.

[6] Xue, C. and Wang, X. (2016) Study on Government Subsidy Decision-Making of Straw Power Generation Supply Chain. 13th Global Congress on Manufacturing and Management.

[7] Zhong, C. and Chen, S. (2013) A Case Study of the Effectiveness of Agricultural Subsidies Policies. Journal of Economics and Development Studies, 1. 


\section{Appendix A}

Implication of the implementation of free Irrigation Service Fee (ISF) to the Federation of Irrigators Associations (FIAs) of Nia-Upriis, Division I.

Interview Guide/Questionnaire:

1) Effects of free ISF on the operation and maintenance of the irrigation system.

a) Ano ang nakikita mong epekto ng programa sa pagmimintina at operasyon ng sistema ng irigasyon?

b) Base sa iyong obserbasyon, anu-ano ang mga pagbabagong naganap mula ng maipatupad ang nasabing programa kung ang serbisyo ng NIA ang pag-uusapan?

2) Actions taken by FIAs in performing their responsibilities in the operation and maintenance of the irrigation system, in compliance with the free ISF program.

a) Ano ang nakikita mong epekto ng programa sa pamamalakad ng inyong samahan?

b) Ano ang mga ginawa ninyong aksyon para matugunan ang inyong responsibilidad ngayong wala ng ISF?

3) Preference of FIAs with regards to payment or non-payment of ISF.

a) Ano inyong naging inisyal na reaksyon sa pagkakalibre ng serbisyo sa bayad patubig (free ISF program)?

b) Ano ang nakikita mong kahalagahan ng pagpapatupad ng programa?

c) Malaking tulong ba ang programa sa mga magsasaka? 